\title{
TWEE BICTERIËHZIEKTEN.
}

Eenige jaren geleden (in 1897) werd door Erwin F. Smith, den bekenden Amerikaanschen phytopatholoog, een ziekte beschreven, die in Amerika verwoestingen had aangericht onder de turnips en vooral onder de kool. Door een nauwkeurig onderzoek kon hij aantoonen, dat een bacterie, die in de houtvaten van de zieke deelen voorkwam, de oorzaak van de ziekte was.

In November j.l. nu werden aan het phytopathologisch laboratorium te Amsterdam eenige zieke koolplanten toegezonden uit Broek op Langendijk (N. H.). Een groot gedeelte van de bladeren was afgevallen; dit was het geval met de onderste, wijder uitstaande bladeren; en van de hooger staande, die den eigenlijken kop vormen, waren de

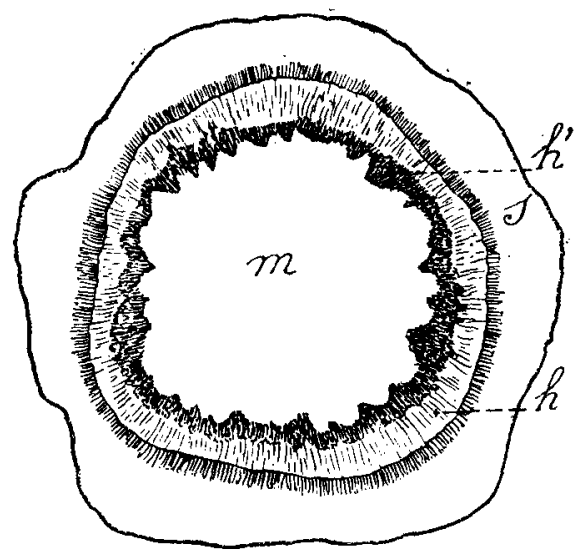

Doorsnede door een door de bacterieziekte aangetasten koolstam : $m$. merg ; $h$. houtgedeelte, dat nog vrij van bacteriën en kleurloos is; $h$ '. houtgedeelte, waarin de bacteriën zich bevinden en dat de donkerbruine kleur heeft; s. schors.

buitenste aan het afsterven ; bij de roode kool hadden ze hun frissche tint verloren en waren slap en leerachtig, bij de witte waren ze geel met bruine randen. Bij de bladeren van 
den kop was soms de bladvoet geheel weggerot en niet zelden strekte de rotting zich verder naar binnen toe uit, zoodat een heele holte uit de kool was weggerot. De stam vertoonde, behalve het gemis der bladeren, uitwendig geen ander ziektesymptoom ; soms echter had de rotting ook hem aangegrepen, zoodat hị scheuren vertoonde en zelfs een enkele maal inwendig geheel hol was. Meestal echter ging het zoover niet, maar alle stengels vertoonden een ander, zeer karakteristiek verschijnsel: nl. zwartkleuring van het houtgedeelte. Sneed men den stam dwarsdoor, dan viel het houtgedeelte als een donkerbruine of zwartgekleurde ring dadelijk in 't oog. Ook het houtgedeelte van de hoofdnerven der bladeren vertoonde soms die donkerbruine tint.

Het ziektebeeld van de kool stemde geheel overeen met de beschrijving, die Erwin Smith van de bovengenoemde bacterieziekte had gegeven, en het mikroskopisch onderzoek bevestigde ons vermoeden, dat wij hier met dezelfde ziekte te maken hadden ; de zwartgekleurde houtvaten uit den stam en de bladnerven bleken nl. opgevuld te zijn met een massa beweeglijke bacteriën. In de plant hebben de bacteriën alle een kogelronde gedaante, kweekt men hen echter op een geschikten voedingsbodem, dan gaat deze kogelronde vorm over in een meer langwerpige.

Hun beweeglijkheid danken zij aan het bezit van één zweephaar aan 't uiteinde van 't staafje. Zij behooren daarom tot het geslacht Pseudomonas en ontvingen den naam Pseudomonas campestris (Pammel).

Dat een plant, waarvan de houtvaten opgevuld zijn met bacteriën, door en door ziek moet zijn, spreekt vanzelf : door de houtvaten worden immers het water en de voedingsstoffen uit den bodem naar de bladeren toegevoerd; en de plant zal dus in alle geval aan die stoffen gebrek lijden, wanneer hare houtvaten door bacteriën verstopt zijn. Dit gebrek zal vooral 
door de jonge, nog groeiende gedeelten gevoeld worden : de groei zal ernstig gestoord zijn. In Amerika werd dan ook waargenomen, dat planten, die in hare jeugd werden geïnfecteerd, in groei sterk achterbleven bij de gezonde en soms bepaald dwergen bleven. Maar ook wanneer de planten op lateren leeftijd besmet worden, gelijkt het ziektebeeld op dat van voedselgebrek: het geel worden en afvallen der bladeren, te beginnen met de onderste en allengs de daarboven gelegen aantastende, is eveneens een verschijnsel, dat zich voordoet, wanneer een plant groeit in een bodem, die arm is aan roedsel bv. aan kali.

Toch zijn de bacteriën nog in andere richting schadelijk: hun afscheidings-producten zijn in 't algemeen stoffen, die nadeelig zijn voor de planten. De bacteriën onthouden dus niet alleen den planten water en voedsel, maar vergiftigen ze ook door hun stofwisselings-producten.

Uit de mededeelingen, die onzeinzender ons verstrekte, bleek, dat de zickte al sedert eenige jaren in Noord-Holland voorkomt : "Voor een jaar of vijf werd zij het eerst waargenomen aan Utrechtsche roode, maar tegenwoordig tast zij nagenoeg alle variëteiten aan,zelfs bloemkool », schreef ons de heer Porte te Winkel (N. H.). " De schade is echter tot dusver het grootst aan roode »..... «W Wij hebben hier met een vijand te doen, die zoo gevreesd wordt, dat sommige pessimisten de toekomst voor de koolbouwers donker inzien ". «Vele hectaren kool worden er tegenwoordig door aangetast, waardoor 7/8, ja zelfs $9 / 10$ van den oogst totaal verloren gaat.»

De schade kan dus zeer aanzienlijk worden; de kwaal trad trouwens ook in Amerika zeer verwoestend op en op sommige plaatsen vreesden de landbouwers zelfs er door genoodzaakt te zullen worden de koolteelt geheel op te geven.

De oorzaak van de snelle uitbreiding, die de ziekte verkrijgt als zij eenmaal is opgetreden, is gelegen in het feit, 
dat de kool zoo bijzonder vatbaar voor de ziekte is en blijkbaar een zeer gering natuurlijk weerstandsvermogen tegen de bacteriën heeft. De infectieproeven, die Erwin Smith nam, toonden dit duidelijk aan : van al dekoolplanten, die hij infecteerde, bleef slechts een zeer gering percentage gezond.

Die proeven brachten echter ook aan het licht, dat ofschoon kool in al zịjn varieteiten, wel de plant is die de meeste vatbaarheid voor de ziekte heeft, de kwaal toch ook andere Brassica-soorten kan aantasten, nl. 'koolrapen(B. napus), turnips (B. rapa), zwart mosterdzaad (B. nigra) en de wilde herik (Sinapis arvensis), en ook de radijs (Raphanus sativus).

Maar deze planten schijnen alle veel minder vatbaar te zijn dan de kool ; alleen wanneer de planten in slechte conditie verkeeren, bv. tengevolge van te groote vochtigheid of te sterke bemesting, heeft de bacterie vat op hen.

Waarom de bacteriën nu uitsluitend in de houtvaten leven, is moeilijk te zeggen. Misschien is het blad- en schorsparenchym voor hen een te zuur substraat, misschien zijn er andere stoffen in die levende weefsels, welke ongunstig voor de bacteriën zijn; maar zeker is het, dat zij in die weefsels eerst tieren kunnen, wanneer de plant reeds in een vergevorderd ziektestadium is en de bedoelde weefsels aan ' $t$ afsterven zijn.

Vóór dien tijd zijn de bacteriën beperkt tot de houtvaten, en wil men een gezonde koolplant infecteeren, dan is het ook zaak te zorgen, dat de bacteriën, waarmee men de plant besmetten wil, in het hout worden gebracht. Heeft men echter daarvoor gezorgd, dan kan men ook zeker zijn, dat over eenige weken de ziekte zich zal vertoonen; de onderste bladen nemen weldra een gele tint aan en worden slap, de rand sterft af en wordt hruin; weldra valt het geheele blad af, terwijl langzamerhand de hooger gelegen bladeren dezelfde ziekteverschijnselen gaan vertoonen en het hout 
van het stengelgedeelte boven de plaats van infectie de typische bruine kleur verkrijgt. Kortom, de plant heeft het karakteristieke ziektebeeld, zooals wij dat boven beschreven hebben.

Het wegrotten van bladeren en stam, wat bij de ons toegezonden koolplanten voorkwam en wat gepaard gaat met ontwikkeling van den hoogst onaangenamen reuk, aan rottende kool eigen, is echter een secundair verschijnsel, dat zich alleen vertoont als de atmosfeer bijzonder vochtig is. Het is het gevolg van de werking van secundaire, saprophytische bacteriën. De vertering van stam- en bladparenchym, die Pseudomonas campestris te weeg brengt, is een droog rot zonder stank.

Ook door de bladeren te infecteeren kan men de plant ziek maken; maar ook hierbij moet men de bacteriën in het hout (in de nerven dus) brengen; een infectie van het bladparenchym blijft gewoonlijk zonder resultaat. Doch het is niet noodig een wond te maken om de bacteriën in het hout te brengen : de z.g. "waterporen », die de plaats van uitmonding der houtvaten zijn, kunnen voor de bacteriën ook als toegangsplaatsen tot de houtvaten dienst doen : door een druppel van een vloeistof waarin de bacteriën zich bevinden op een waterpore te brengen, kan men - volgens Erwin Smith - de infectie bewerken.

Hoe zal nu echter in de natuur de besmetting plaats vinden, hoe zullen de bacteriën in de gelegenheid gesteld worden in de houtvaten te komen? Erwin Smith vermoedt dat dit gedeeltelijk door middel van de waterporen plaats vindt; maar dat verder allerlei dieren, die aan de bladeren van de kool vreten (slakken, koolrupsen) of in wortel of stam indringen (larven van de koolvlieg, ritnaalden, engerlingen, aardvlooien), in staat zịjn die infectie te bewerkstelligen, wanneer de omgevende grond door de bac- 
teriën besmet is. De proef, die hij nam, bevestigde zijn vermoeden. Slakken, die hij eerst gedurende een paar minuten had gedompeld in een oplossing, waarin zich de bacteriën bevonden, liet hij, gedurende eén nacht vreten aan een paar gezonde koolplanten. Den volgenden dag bleken de slakken hier en daar een stukje uit het blad gevreten te hebben; na verloop van een paar weken was de bruinkleuring der vaatbundels, uitgaande van sommige der aangevreten plaatsen, reeds te zien, weldra breidde de ziekte zich over het blad uit en de bacteriën bereikten den bladsteel en den stam.

Aan de ons toegezonden planten was wegens het vergevorderd ziektestadium niet meer met zekerheid uit te maken waar de infectie had plaats gevonden. Maar onze inzender, de heer Porte, dien wij verzocht hadden eens na te gaan, waar de bruinkleuring pleegt te beginnen, antwoordde ons ; "Wij zijn tot de conclusie gekomen (dat de bacteriën hun intrede) niet in de bladeren (doen). Bij vele koolen zijn de buitenste bladen volkomen gezond, terwijl in de kool ziekelijke nerven voorkomen, correspondeerende met de houtvaten van den stam. Verscheiden koolen worden tegenwoordig nog verkocht, waaraan uiterlijk niets is te bespeuren, maar waarvan alleen de doorsnee van den stam op de bekende wijze de ziekte verraadt. Tracht men ze te bewaren, dan blijkt het over eenige dagen of weken, dat ze ongeschikt zijn voor overwintering, hoe gaaf ze zich ook voor 't oog voordeden. De infectie schijnt dus hier in den stam begonnen te zijn. " De heer Porte deelde ons nog verder mee : "Algemeen is men hier van oordeel, dat de besmetting reeds plaats heeft gehad op de plantenbedden.... Bekend is het, dat planten van bepaalde bedden overal ziek werden, terwijl planten van andere bedden, die op dezelfde akkers werden geplant, volkomen goed bleven. Moet hier 
aan besmetting door schadelijke dieren worden gedacht, dan komen dus in de eerste plaats in aanmerking de aardvlooien, die hier de laatste voorjaren in grooten getale optraden.

Verder heeft men veel last van slakken en ratten. »

Ter bestrijding van de ziekte, is het verwijderen van de aangetaste planten, zoodra de ziekte zich vertoont een eerste vereischte. Dit zal reeds op de plantbedden moeten plaats vinden; maar ook bij het overbrengen van de planten naar de akkers zal met zorg moeten worden toegezien, dat alleen volkomen gezonde en onbeschadigde planten worden uitgepoot, alle zieke of verdachte planten moeten verwijderd en onschadelijk gemaakt worden. Men moet voorts vermijden, alle koolafval, zelfs die van gezonde planten, op het land te laten liggen, zooals toch gewoonlijk geschiedt. Door dien afval te verwijderen, bereikt men een tweeledig doel : ten eerste worden de massa's bacteriën, die in den afval van zieke planten zitten, van het land verwijderd, maar met hen een groot aantal schadelijke dieren, die als overbrengers van de ziekte kunnen optreden en die in den afval zijn achtergebleven of er hun eieren in gelegd hebben. Alle andere middelen, die ter bestrijding van die schadelijke dieren worden aangewend, dienen natuurlijk ook indirect. ter bestrijding der bacteriën.

De zieke planten kunnen worden verbrand of, onder toevoeging van ongebluschte kalk, worden ingegraven. Deze wordt vervolgens met water gebluscht, zoodat door de hooge temperatunr welke daarbij ontstaat, alle organismen gedood worden. In geen geval mogen de planten echter op de mestvaalt geworpen of aan de dieren te eten gegeven worden; de bacteriën zouden dan immers met den mest wederom op het land geraken.

Een gepaste wisselbouw is ook hierbij zeer gewenscht: door het jaar in jaar uit uitzaaien en telen van kool op het- 
zelfde bed of het verbouwen op hetzelfde land, verschaft men allen parasieten van kool, ook den bacteriën, een gunstige gelegenheid zich sterk te vermenigvuldigen en hun vernielingswerk van jaar op jaar grooter uitbreiding te geven. En vooral mag niet op land, waar zich de bacteriënziekte vertoond heeft, een volgend jaar weer kool verbouwd worden of een ander gewas, dat voor de ziekte vatbaar kan zijn (koolzaad, mosterzaad, koolrapen, turnips, radijs).

De bacteriën zijn niet kieskeurig in hun voedsel : zij groeien welig op gelatine, op aardappelschijfjes, op aftreksel van uien, op schijfjes wortel, enz.; en al is de proef er nog niet meegenomen, toch kan menverzekerd zijn, dat ook dierlijke mest een geschikt substraat voor hen is. Met het oog op deze ziekte verdient kunstmest dus den voorkeur boven natuurmest.

Al is het aantal plantenziekten, die door bacteriën veroorzaakt worden, in vergelijking van dat der ziekten, welke zwammen teweeg brengen, zeker zeer gering, toch zijn in de laatste jaren meer en meer ziekten bekend geworden, die aan de werking van bacteriën moeten toegeschreven worden. Wel blijft het opvallend, dat, terwijl bij de dieren de bacteriën als ziekteverwekkers veel belangrijker zijn dan de zwammen, dit bij de planten juist omgekeerd is; maar dat bacteriënziekten bij de planten niet zouden voorkomen (zooals men vroeger dacht) is gebleken onjuist te zijn. Er gaat geen jaar voorbij of nieuwe plantenziekten worden bekend, waarvan bacteriën de oorzaak zijn.

Zoo waren wij in den loop van dit jaar in de gelegenheid, een bacterieziekte te onderzoeken, die bij een kweeker te Haarlem optrad onder de zomerviolieren (Cheiranthus annurus) en die in vele opzichten overeenkomst heeft met de boven beschreven bacterieziekte der kool : de bladeren 
werden geel en vielen af, het houtgedeelte van den wortel bleek op de doorsnee bruin gekleurd te zijn, en ook hier bleken de houtvaten gevuld met bacteriën, die echter niet een kogelronden maar een langgerekten, dunnen staafvorm hadden. Zij hadden zich verspreid door de houtvaten van den stam omhoog en ook in 't hout der onderste takken waren de parasieten reeds te vinden. De wortel ging aan het uiteinde afsterven en kromp hierbij samen, zoodat het doode uiteinde als een bruingekleurd en ingeschrompeld gedeelte scherp tegen het nog gezonde hoogergelegen wortelgedeelte afstak. Prof. Beyerinck was zoo goed de bacteriën voor ons te cultiveeren op vleeschgelatine; hij deelde ons mee, dat de cultuur direct een reincultuur was geweest : het hout was dus niet gevuld geweest met bacteriën van verschillende soorten, zooals dat het geval is, wanneer organen, die aan 't afsterven zijn, door bacteriën worden aangetast, m.a.w. wanneer in de vrije natuur bacteriën saprophytisch optreden, maar het was één bepaalde soort bacteriën die zich in het hout genesteld had. Dit gevoegd bij het feit, dat de bacteriën zich ook bevonden in overigens nog volkomen gezonde weefsels (bovenste wortelgedeelte, stam en takken) doet ons besluiten, dat de bactërien bij deze ziekte wel degelijk als parasieten zijn opgetreden en als de oorzaak ervan moeten worden beschouwd.

Wij waren nog niet in de gelegenheid de ziekte in bije zonderheden na te gaan. Waar de infectie begint, hoe zij tot stand komt, of ook hierbij schadelijke insecten een rol spelen, of nog andere planten vatbaar zijn voor deze kwaal - op al die vragen kunnen wij thans nog geen antwoord geven. Wellicht treedt een volgend jaar deze ziekte nogmaals in deze of gene kweekerij op en zijn wij in de gelegenheid, haar nader na te gaan.

Amsterdam, den $4^{n}$ December 1900.

C. J. J. Van Hahl. 


\section{Verklaring van plaat 12}

1. Zieke roode-kool plant; bij $\mathbf{x}$ is een deel van den kop weggerot.

2. Zieke savoye-kool; de stam is doorgesneden en vertoont bij $\mathbf{x}$ den zwartgekleurden houtring.

\section{PROF. RÖRIG'S OHDERZOENIKGEN OVER DE VOEDING VAN SOMMIGE ROOFVOGELS.}

In de eerste aflevering (1900) van het eerste deel der "Arbeiten aus der biologischen Abtheilung für Landund Forstwirthschaft am Kaiserlichen Gesundheitsamle” te Berlijn, is een verhandeling verschenen van Prof. $D^{r}$ RöRIG(1) over den inhoud van de maag bij een aantal vogels, die voor den land- en boschbouw belangrijk zijn. Wij zullen ons hier alleen met de roofvogels bezig houden.

De uitkomsten, die Rörig daarbij verkregen heeft, brengen natuurlijk niet uitsluitend of zelfs niet veel nieuwe feiten aan het licht; immers, voor vele vogels, en vooral voor roofvogels, die door hunne grootte en hunne leefwijze meestal vrij sterk van de andere vogels onzer streken afwijken en dus meer de aandacht opwekken, weet men nagenoeg met zekerheid, waaruit hunne voeding bestaat en of ze als nuttig, dan wel als schadelijk voor land- en boschbouw dienen beschouwd te worden. De onderzoekingen van RöRIG zijn niettemin zeer belangrijk, daar zij niet alleen over 't algemeen de waarnemingen van anderen komen bevestigen, maar tevens feiten en cijfers leveren, die in vele gevallen uitstekend geschikt zijn om sommige vooroordeelen tegen bepaalde dieren te bestrijden.

Wij laten hier nu de belangrijkste uitslagen, die Prof.

(1) Magenuntersuchungen land- und forstwirthschaftlich wichtiger Vögel. 


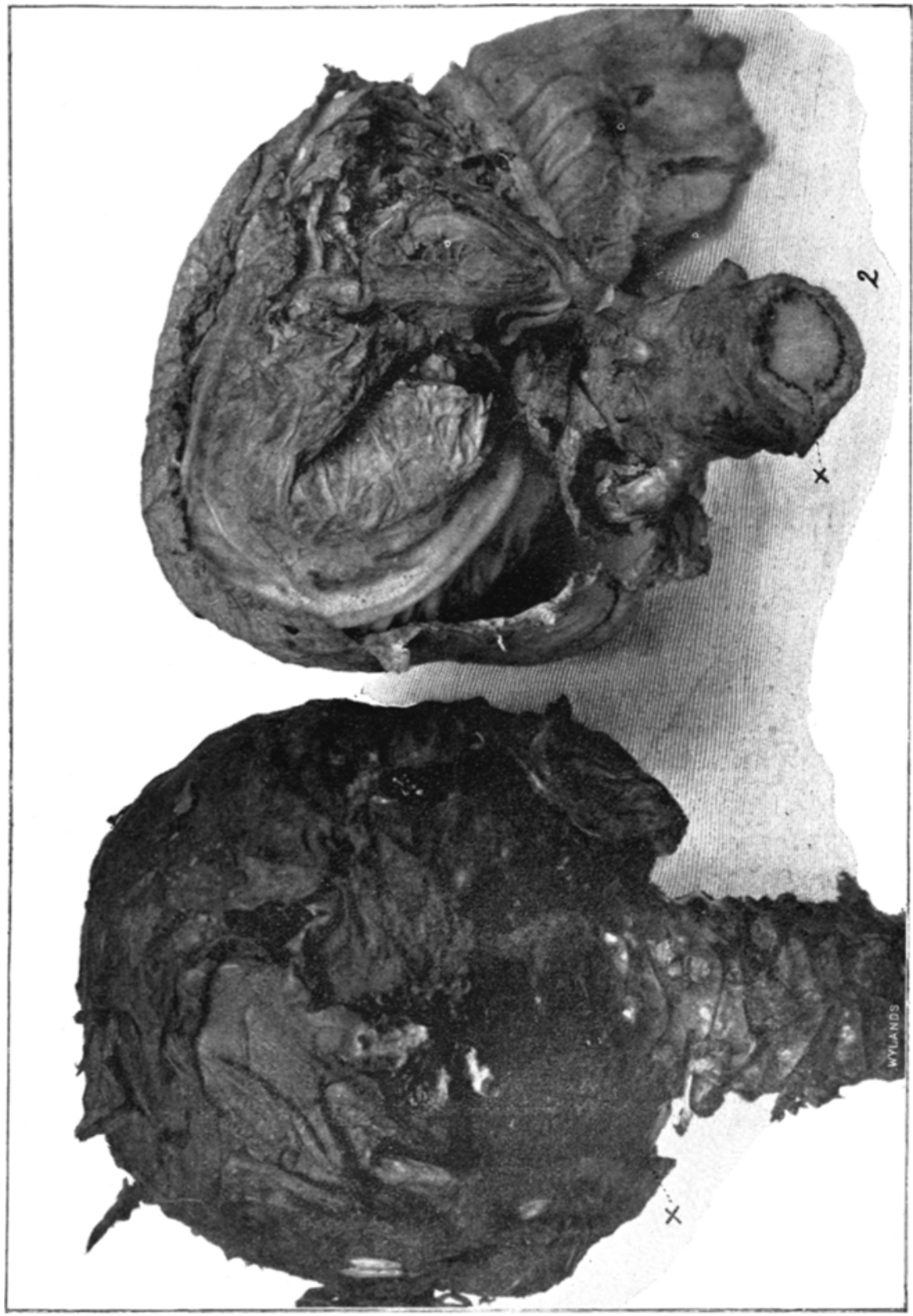

